TAO, Supplementary Issue, 269-286, May 2001

\title{
Seismogenic Zones in the Convergent Margin, Eastern Taiwan and Its Implications in the Luzon Forearc Deformation
}

\author{
Win-Bin Cheng ${ }^{1, \star}$ and Chengsung Wang ${ }^{2}$
}

(Manuscript received 27 December 2000, in final form 15 February 2001)

\begin{abstract}
Three-dimensional relocated seismicity in eastern Taiwan reveals two north-to-northeast trending seismogenic zones, one located close to the Longitudinal Valley and the other near to the crest of the Luzon arc. Earthquake focal mechanisms obtained from P-wave first motion polarity data are presented in this study for $\mathbf{7 0}$ events in these two seismic zones. The focal mechanism solutions for both seismic zones show mainly thrust and strike-slip faulting in the area south of $23.2^{\circ} \mathrm{N}$. The horizontal projection of the events' P-axis indicates a pattern consistent with the regional NW-SE compression. However, the orientation of the events' $T$-axes indicates that there are different patterns for the two seismic zones. By combining evidence from seismicity, P- and T-axes, as well as detailed bathymetry, we infer that the two seismic zones (fault systems) might mark the east and west boundaries of the Luzon forearc. According to the transpressional strain model proposed in this study, the Luzon forearc represents a deforming zone, between two relatively rigid blocks, that undergoes shearing from the transcurrent component of oblique convergence in eastern Taiwan.
\end{abstract}

(Key words: Seismogenic zone, Focal mechanism, Luzon forearc)

\section{INTRODUCTION}

In eastern Taiwan, the Longitudinal Valley fault is considered to represent the oblique collisional boundary between the Philippine Sea plate, which carries the Luzon volcanic arc, and the Eurasian plate (Fig. 1) (e.g., Barrier and Angelier 1986; Ho 1986; Tsai 1986). Global Positioning System (GPS) measurements, collected from 1990 to 1995 (Yu et al. 1997), suggested that about $60 \%$ of the plate convergence is accommodated by deformation between the

\footnotetext{
${ }^{1}$ Department of Visual Communication Design, Jin-Wen Institute of Technology, Hsin-Tein, Taiwan

${ }^{2}$ Institute of Applied Geophysics, National Taiwan Ocean University, Taipei, Taiwan

* Corresponding author address: Dr. Win-Bin Cheng, Department of Visual Communication Design, JinWen Institute of Technology, 99 Ann-Chung Road, Hsin-Tein, Taipei County, Taiwan E-mail: wbin@jwit.edu.tw
} 


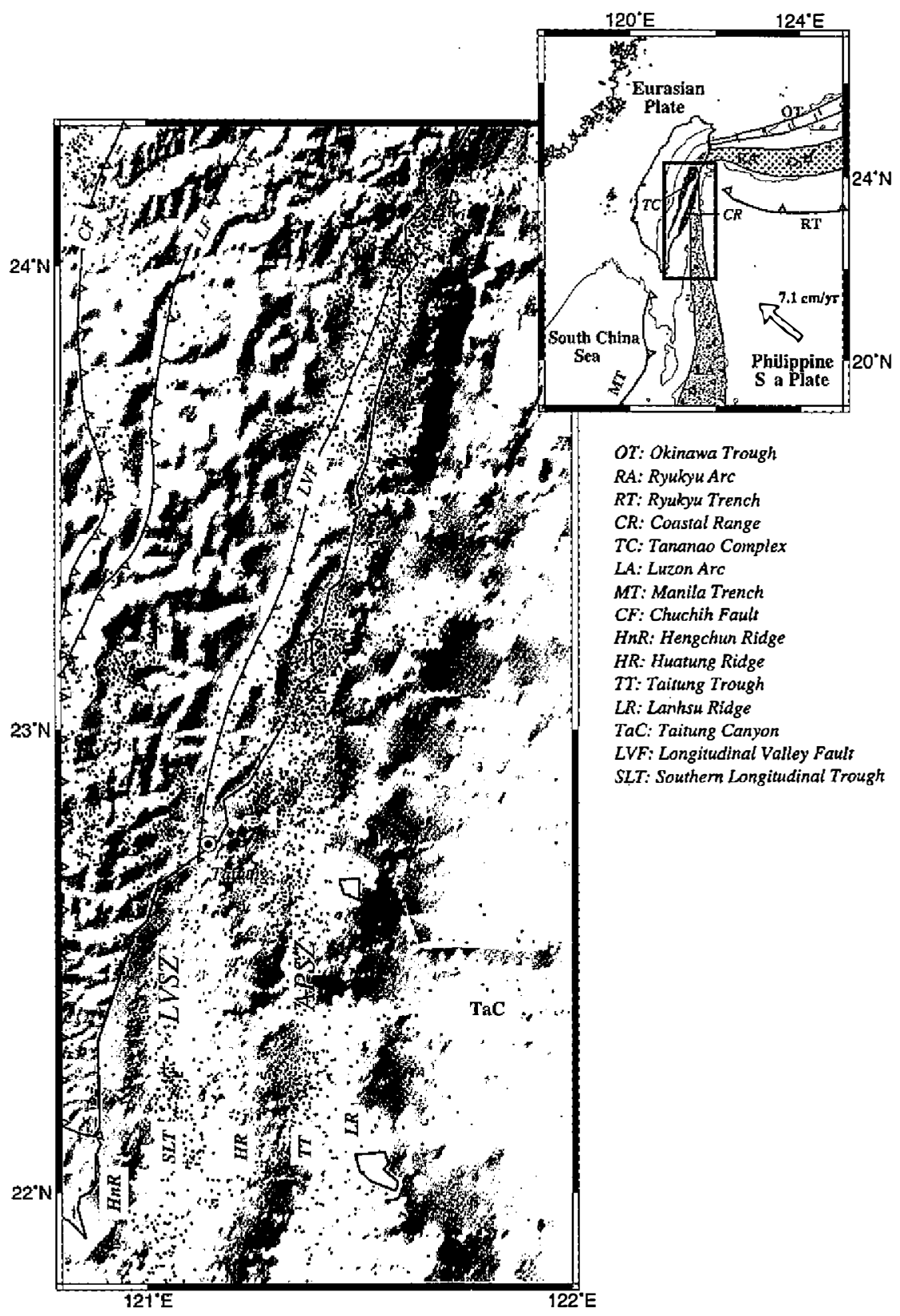

Fig. 1. Bathymetry, seismicity (solid circles), tectonic framework, and main structural unit map for eastern Taiwan. Geodynamic setting in the upper-right. Major thrust faults with open triangles on the upper side. Hypocenters of earthquakes were relocated with 3-D velocity model of Cheng et al. (1999). LVSZ: Longitudinal Valley seismic zone; APSZ: arc-paralleI seismic zone 
eastern flank of the Central Range and the Luzon arc (Fig. 2). It has been thought that the shortening in this region is accomplished by transfer of slip (e.g., Lundberg et al. 1997) and forearc deformation (e.g., Chemenda et al. 1997; Cheng et al. 1999). Oblique convergence also gives way to high seismicity, including the left-lateral slip observed in the northerm Longitudinal Valley (Hsu 1962) and thrust events (Wu 1989; Kao et al. 1998; Kao et al. 2000). The deformation of the Luzon forearc basin is also evident in seismic reflection data (Fuh et al. 1997; Lundberg et al. 1997). A recent study on earthquake relocation and tomography of the eastern Taiwan area (Cheng et al. 1999) reported two sub-parallel seismic zones-one located close to the Longitudinal Valley and the other located west of the Luzon arc's crest (Fig. 1). However, what is the main type of faulting for these two seismic zones? Do their mechanisms vary as the collision between the Luzon volcanic arc and Taiwan increases from south to north? And, what is the relationship between the genesis of these two seismic zones and the deformation of the Luzon forearc?

Here we address these questions by studying the focal mechanisms of earthquakes of magnitude $M_{L} \geq 3$ and mostly shallower than $30 \mathrm{~km}$, in the eastern Taiwan area. We use hypocenters relocated with three-dimensional velocity model (Cheng et al. 1999). Horizontal and depth standard errors for these events are mostly less than $2 \mathrm{~km}$ and $3 \mathrm{~km}$, respectively. This is also the level of the largest changes caused by small changes in the model, such as whether or not station corrections are included. The events we have studied are relatively small and do not represent the total convergence in the region due to relative motion of the Philippine Sea and Eurasian plates. This will occur in large earthquakes on the major faults (e. g., 1951 Longitudinal earthquakes, $M_{L}=7.3,7.1$, and 7.3) that are presently quiescent, a fact that is reflected in the present diffuse seismicity throughout the region. However, we believe that this type of study can give a useful insight into the present state of convergence in this area.

\section{TECTONIC SETTING}

Taiwan is the result of active, oblique collision between the Eurasian and Philippine Sea plates. Oblique collision has formed several mountain ranges and can be divided into two geological provinces by the Longitudinal Valley fault (Fig. 1). To the east of the fault is the Coastal Range which is mainly composed of Miocene to Pliocene andesitic volcanic units and associated flyschoid and turbidite sediments. To the west of the fault is the main body of Taiwan, distinguishable into the Central Range and the Hsüehshan Range, which is composed of a pre-Tertiary metamorphic basement overlain by Paleogene low-grade metamorphosed sediments, Neogene folded and thrusted sedimentary rock layers and Quaternary alluvial deposits (Ho 1986). The Hsüehshan Range is separated from the Central Range by the Lishan fault (LF), which branches off from the Chuchih fault (CF). The Chuchih fault is a major upthrust fault which follows the contact between the slat belt and the fold-and-thrust belt of the western foothill region (Ho 1982). The Foothill zone is a province of typical cover tectonics in which only late Tertiary and Quaternary rocks are involved (Fig. 1).

The southeastern Taiwan area is a transitional zone from a typical subduction system to the south into a collision zone to the north (Fig. 1). Based on a morphological study, Chen and 
(a)

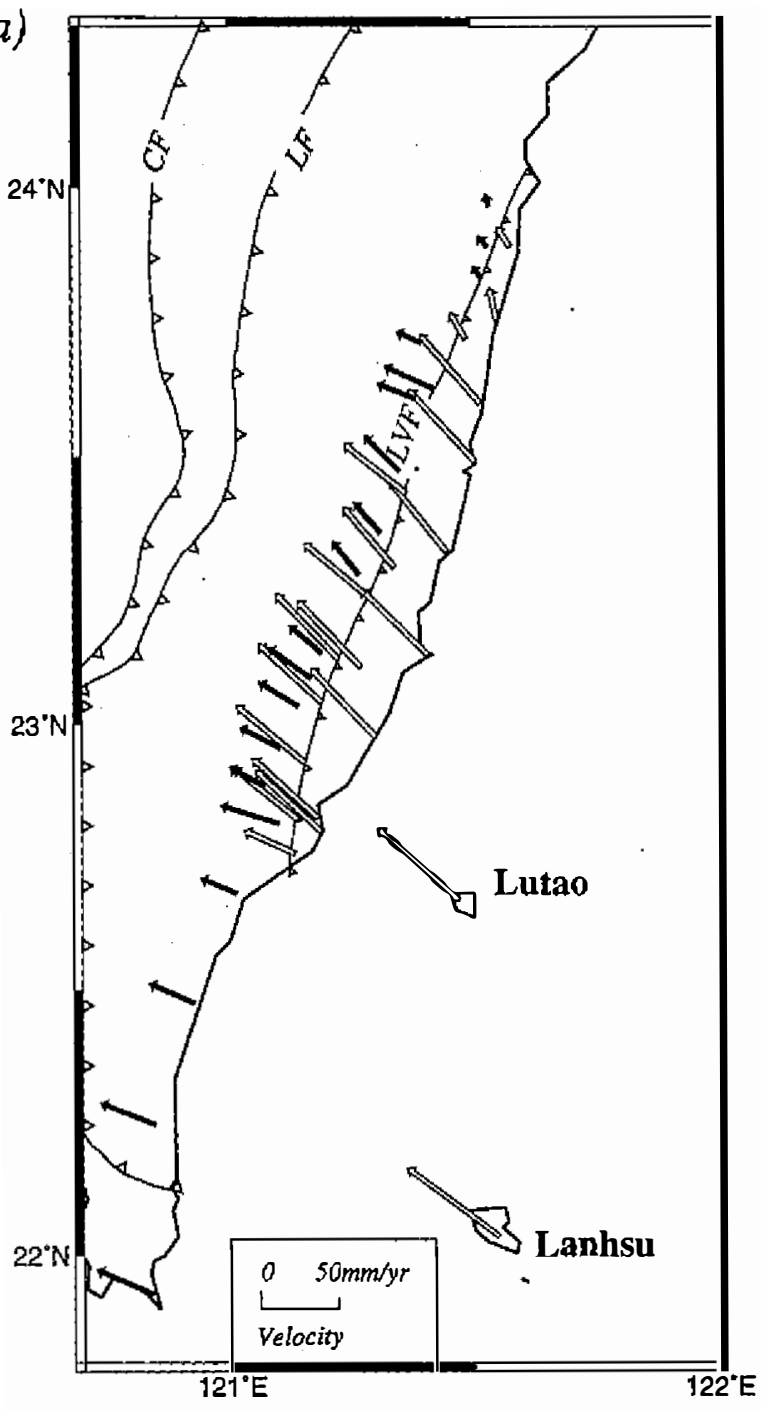

Fig. 2. (a) Velocities of GPS stations in eastern Taiwan reported by Yu et al. (1997). Black arrows indicate the velocities of the GPS stations located west of the Longitudinal Valley fault (LVF), while the white ones are stations located east of the LVF. (b) Velocities of GPS stations plotted as a function of latitude. Note that about $60 \%$ of the plate convergence is accommodated between the eastern flank of the Central Range and Luzon arc.

(b)

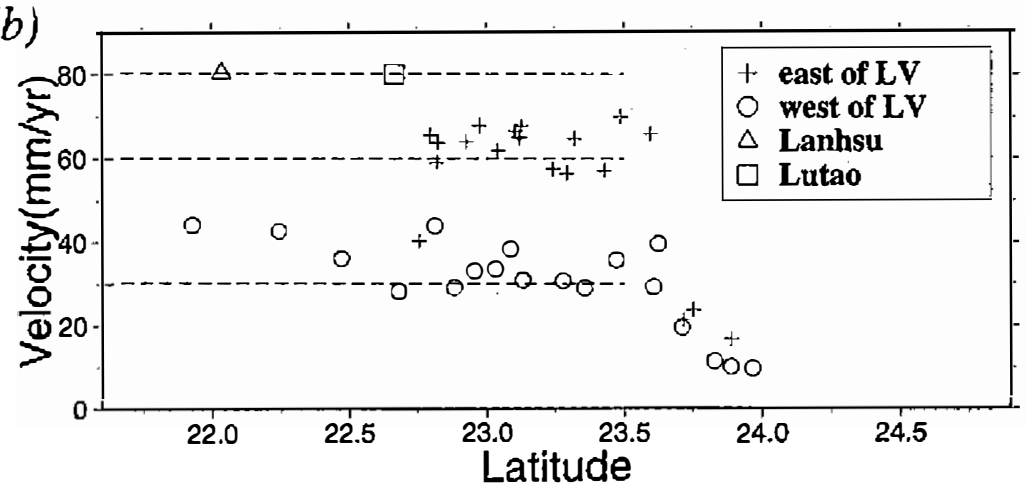


Juang (1986) divided the southeastern offshore area of Taiwan into five physiographic zones: the Hengchun Ridge, the Southern Longitudinal Trough, the Huatung Ridge, the Taitung Trough and the Lanhsu Ridge, from west to east (Fig. 1). Using magnetic and gravity data, Liu et al. (1992) indicated that the material at the basement of the Taitung Trough belongs to a volcanic arc, whereas the basements of the Southern Longitudinal Trough and Huatung Ridge do not. The Taitung Trough, the northern part of the North Luzon Trough, narrows with observable shoals toward the north and ends at the southern Coastal Range on eastern Taiwan (Page and Suppe 1981). Lutao and Lanhsu are the two northernmost islands of the Lutao-Babuyan ridge of the Luzon volcanic arc (Bowin et al. 1978). Radiometric dating shows that as you move southward along this ridge, the volcanoes are younger in this ridge belt (Richard et al. 1986). Based on magnetic basement boundary analysis, Shyu et al. (1996) also concluded that the Luzon Arc has started subsiding northward. In this part of the Luzon arc, the main volcanic activity ceased in the middle Miocene (Ho 1982, 1986). The Luzon arc presumably continues northward to include the Chimei Igneous Complex in the middle of the Coastal Range of Taiwan (Ho 1986).

\section{DATA AND ANALYSIS}

We study the focal mechanisms of earthquakes of magnitude $M_{L}$ greater than 3.0, and mostly shallower than $30 \mathrm{~km}$, in eastern Taiwan. Mechanisms have been determined for individual events using first motion polarity data. Arrival times and polarities were picked from digital seismic data recorded by the Central Weather Bureau Seismographic Network (CWBSN) during 1990 to 1998. The hypocenters were relocated with the local earthquake tomographic scheme (Thurber and Eberhart-Phillips 2000) using the three-dimensional velocity model determined for eastern Taiwan (Cheng et al. 1999). We have obtained good values of root mean square (RMS) residuals for most earthquakes analyzed.

The focal mechanism solutions were calculated with the FPFIT program (Resenberg and Oppenheimer 1985). The estimated uncertainties on strike, dip and rake of the fault-plane solutions are less than $20^{\circ}$ and involve at least ten polarities. In order to test further the structural significance of the solutions, we selected ten of the events and analyzed them in detail. We decided to test the focal mechanisms of fixed hypocentral depths, shifting the hypocenter to $15 \mathrm{~km}$ and then to $1 \mathrm{~km}$. In general, more stable solutions were obtained, for earthquakes where we have both good azimuthal coverage and many polarity data. Large azimuthal gaps, however, led to larger variations.

\section{RESULTS}

Spatial distribution of 8334 relocated hypocenters shows that there are two sub-parallel seismic groupings in eastern Taiwan-the Longitudinal Valley seismic zone (hereinafter referred to as the LVSZ) and the arc-parallel seismic zone (hereinafter referred to as the APSZ) (Fig. 1).

Figure 3 shows fault plane solutions for 70 events in eastern Taiwan. Details of the focal parameters, locations and references to these earthquakes are given in Table 1. It is clear from 


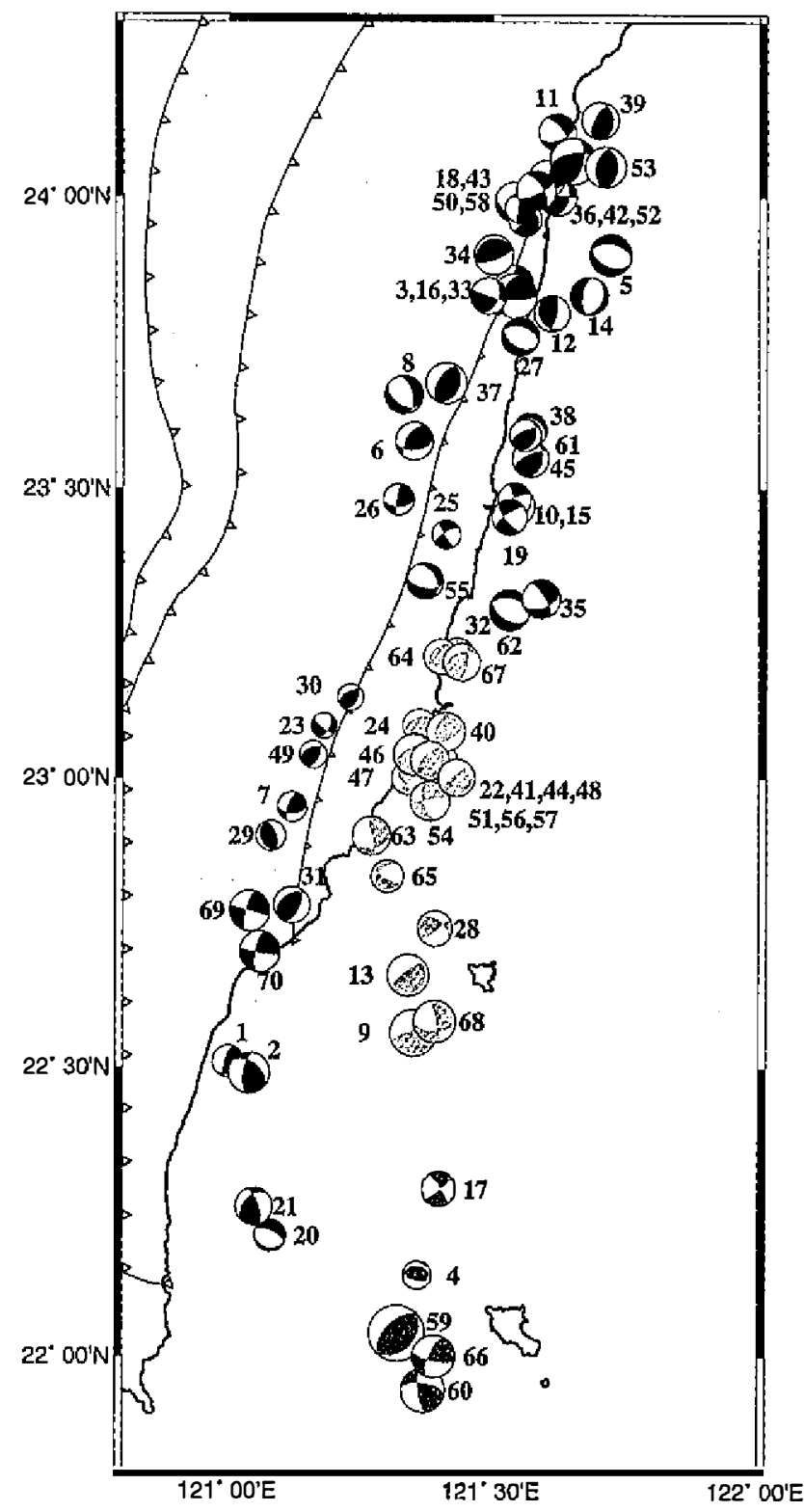

Fig. 3. Epicenters and focal mechanisms of earthquakes determined for eastern Taiwan. All equal-area projections of the lower focal hemispheres with compressional quadrants are shaded. The numbers show the event's number in Table 1. Events are from this work and other sources mentioned in the text.

Fig. 3 that the focal mechanisms of events determined in this study show a complex pattern for the APSZ and LVSZ. However, if we roughly divide these events into two groups, they predominantly show thrust (events 1, 2, 4, 9, 13, 22, 24, 29, 31, 40, 41, 44, 48, 49, and 59) and strike-slip solutions (events $21,60,66,68,69$, and 70) for the APSZ and LVSZ in the area south of $23.2^{\circ} \mathrm{N}$. On the other hand, there are several normal solutions observed (events 5,8 , $14,27,55$, and 62 ) for both seismic zones in the area north of $23.2^{\circ} \mathrm{N}$. Strike-slip solutions (events 15,17, 19, 28, 47, 54, 63, and 65) are observed in the area between the APSZ and LVSZ. 
Table 1. Summary of Source Parameters.

\begin{tabular}{|c|c|c|c|c|c|c|c|c|c|c|c|c|c|c|c|}
\hline $\begin{array}{l}\text { Letters on } \\
\text { Fig. } 3\end{array}$ & Date $^{a}$ & $\begin{array}{c}\text { Origin } \\
\text { Time, } \\
\text { UT }\end{array}$ & $\begin{array}{c}\text { Lat., }^{a} \\
{ }^{\circ} \mathrm{N}\end{array}$ & $\begin{array}{c}\text { Lon., } \\
{ }^{\circ} \mathrm{E}\end{array}$ & $\begin{array}{l}\text { Depth }^{\mathrm{a}} \\
(\mathrm{Km})\end{array}$ & $\begin{array}{c}\text { Local } \\
\text { Magnitude }^{\mathrm{a}}\end{array}$ & 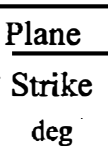 & $\frac{1}{\begin{array}{c}\text { Dip } \\
\operatorname{deg}\end{array}}$ & 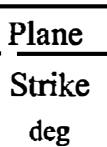 & $\begin{array}{c}2 \\
\text { Dip } \\
\operatorname{deg}\end{array}$ & $\frac{P}{\text { Azimuth }}$ & 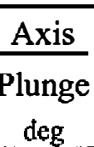 & $\frac{\mathrm{T}}{\text { zimuth }}$ & 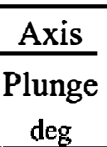 & Reference $^{b}$ \\
\hline 1 & Oct. 16,1986 & $02: 08$ & 22.51 & 121 & 3 & 4.02 & 60 & 25 & 197 & 71 & 300 & 24 & 83 & 61 & $\mathrm{C} 1995$ \\
\hline 2 & Nov. 29,1986 & $22: 50$ & 22.49 & 121.04 & 11.51 & 5.16 & 190 & 65 & 307 & 46 & 253 & 11 & 148 & 52 & $\mathrm{C} 1995$ \\
\hline 3 & Dec. 18,1990 & $04: 39$ & 23.85 & 121.54 & 1.19 & 4.79 & 275 & 85 & 184 & 80 & 140 & 11 & 49 & 4 & $\mathrm{~T}$ \\
\hline 4 & Feb. 4, 1991 & $23: 17$ & 22.14 & 121.36 & 15.77 & 3.52 & 100 & 55 & 280 & 35 & 190 & 10 & 10 & 80 & $\mathrm{~T}$ \\
\hline 5 & Mar. 2, 1991 & $18: 13$ & 23.9 & 121.72 & 12.86 & 5.21 & 115 & 45 & 281 & 46 & 112 & 82 & 18 & 1 & $\mathrm{~T}$ \\
\hline 6 & May. 7, 1991 & $04: 36$ & 23.58 & 121.35 & 10.2 & 4.74 & 85 & 50 & 212 & 54 & 328 & 2 & 62 & 61 & $\mathrm{~T}$ \\
\hline 7 & Jun. 25, 1991 & $15: 46$ & 22.95 & 121.12 & 1.12 & 3.76 & 90 & 55 & 198 & 66 & 322 & 7 & 58 & 44 & $\mathrm{~T}$ \\
\hline 8 & Sep. 4, 1991 & $12: 59$ & 23.66 & 121.33 & 13.46 & 4.8 & 125 & 45 & 344 & 52 & 316 & 70 & 56 & 4 & $\mathrm{~T}$ \\
\hline 9 & Sep. 30, 1991 & $09: 44$ & 22.56 & 121.35 & 15.56 & 5.89 & 80 & 10 & 250 & 80 & 342 & 35 & 158 & 55 & K2000 \\
\hline 10 & Nov. 3, 1991 & $04: 17$ & 23.47 & 121.54 & 40.75 & 5.11 & 55 & 85 & 147 & 70 & 103 & 10 & 9 & 18 & $\mathrm{~T}$ \\
\hline 11 & Nov. 5, 1991 & $09: 36$ & 24.11 & 121.62 & 27.83 & 4.66 & 70 & 55 & 322 & 66 & 282 & 44 & 18 & 7 & $\mathrm{~T}$ \\
\hline 12 & Nov. 20,1991 & 03:19 & 23.8 & 121.61 & 6.16 & 4.51 & 150 & 30 & 14 & 67 & 89 & 20 & 316 & 63 & $\mathrm{~T}$ \\
\hline 13 & Dec. 5, 1991 & $15: 48$ & 22.66 & 121.34 & 24.6 & 5.24 & 20 & 20 & 232 & 73 & 314 & 27 & 157 & 61 & $\mathrm{~T}$ \\
\hline 14 & Dec. 28,1991 & $21: 34$ & 23.83 & 121.68 & 9.31 & 4.76 & 20 & 30 & 188 & 61 & 83 & 73 & 282 & 16 & $\mathrm{~T}$ \\
\hline 15 & Jan. 13, 1992 & $\infty 0: 29$ & 23.48 & 121.54 & 39.05 & 4.15 & 250 & 80 & 340 & 90 & 115 & 7 & 205 & 7 & $\mathrm{~T}$ \\
\hline 16 & Apr. 19, 1992 & 18:32 & 23.83 & 121.54 & 13.72 & 5.55 & 90 & 75 & 197 & 42 & 151 & 20 & 40 & 45 & $\mathrm{~T}$ \\
\hline 17 & May. 22, 1992 & $00: 10$ & 22.29 & 121.4 & 19.28 & 4.24 & 55 & 85 & 324 & 80 & 280 & 11 & 189 & 4 & $\mathrm{~T}$ \\
\hline 18 & May. 31, 1992 & $13: 16$ & 23.83 & 121.49 & 20.57 & 4.6 & 20 & 45 & 290 & 90 & 345 & 30 & 235 & 30 & $\mathrm{~T}$ \\
\hline 19 & Jan. 5, 1993 & 19:03 & 23.45 & 121.53 & 6.91 & 4.46 & 140 & 70 & 237 & 71 & 99 & 28 & 8 & 1 & $\mathrm{~T}$ \\
\hline 20 & Mar. 5, 1993 & $12: 56$ & 22.21 & 121.08 & 14.54 & 4.04 & 105 & 25 & 296 & 65 & 216 & 70 & 23 & 20 & $\mathrm{~T}$ \\
\hline 21 & Mar. 7, 1993 & 08:29 & 22.26 & 121.05 & 12.22 & 4.63 & 340 & 70 & 228 & 44 & 98 & 16 & 207 & 49 & $\mathrm{~T}$ \\
\hline 22 & Mar. 28, 1993 & 09:07 & 23.03 & 121.4 & 30.82 & 4.16 & 25 & 55 & 222 & 36 & 122 & 10 & 261 & 78 & $\mathrm{~T}$ \\
\hline 23 & Apr. 15, 1993 & $16: 45$ & 23.09 & 121.18 & 19.17 & 3.28 & 25 & 55 & 127 & 74 & 352 & 37 & 252 & 12 & $\mathrm{~T}$ \\
\hline 24 & Jul. 2, 1993 & $02: 39$ & 23.09 & 121.36 & 18.23 & 4.16 & 40 & 45 & 247 & 48 & 324 & 2 & 228 & 77 & $\mathrm{~T}$ \\
\hline
\end{tabular}


Table 1. (continued)

\begin{tabular}{|c|c|c|c|c|c|c|c|c|c|c|c|c|c|c|c|}
\hline $\begin{array}{l}\text { Letters on } \\
\text { Fig. } 3\end{array}$ & Date $^{a}$ & $\begin{array}{c}\text { Origin } \\
\text { Time } \\
\text { UT }\end{array}$ & $\begin{array}{l}\text { Lat., } \\
{ }^{\circ} \mathrm{N}\end{array}$ & $\begin{array}{l}\text { Lon., } \\
{ }^{\circ} \mathrm{E}\end{array}$ & $\begin{array}{l}\text { Depth }^{a} \\
(\mathrm{~K} m)\end{array}$ & $\begin{array}{c}\text { Local } \\
\text { Magnitude }^{\mathrm{a}}\end{array}$ & 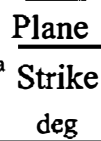 & $\begin{array}{c}\frac{1}{\text { Dip }} \\
\operatorname{deg}\end{array}$ & 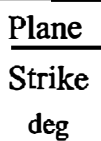 & $\frac{2}{\begin{array}{c}\text { Dip } \\
\text { deg }\end{array}}$ & $\frac{\mathbf{P}}{\text { Azimuth }}$ & 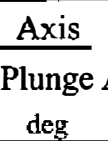 & $\frac{\mathrm{T}}{\text { zimuth }}$ & 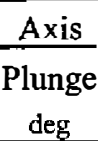 & Reference $^{\mathrm{b}}$ \\
\hline 25 & Jul. 25, 1993 & $03: 52$ & 23.42 & 121.41 & 19.65 & 3.62 & 240 & 75 & 147 & 80 & 103 & 18 & 194 & 4 & $\mathrm{~T}$ \\
\hline 27 & Sep. 30, 1993 & 14:15 & 23.76 & 121.55 & 5.12 & 4.77 & 120 & 45 & 286 & 46 & 117 & 82 & 23 & 1 & $\mathrm{~T}$ \\
\hline 28 & Nov. 13, 1993 & $11: 18$ & 22.74 & 121.39 & 9.52 & 4.36 & 50 & 80 & 312 & 51 & 175 & 19 & 279 & 35 & $\mathrm{~T}$ \\
\hline 29 & Nov. 28,1993 & $23: 35$ & 22.9 & 121.08 & 12.17 & 3.71 & 160 & 30 & 340 & 60 & 70 & 15 & 250 & 75 & $\mathrm{~T}$ \\
\hline 30 & Feb. 2, 1994 & $19: 51$ & 23.14 & 121.23 & 13.14 & 3.33 & 25 & 45 & 244 & 52 & 316 & 4 & 216 & 70 & $\mathrm{~T}$ \\
\hline 31 & May. 23, 1994 & $04: 22$ & 22.78 & 121.12 & 17.56 & 4.59 & 25 & 55 & 237 & 40 & 129 & 8 & 244 & 71 & $\mathrm{~T}$ \\
\hline 32 & Jun. 9, 1994 & $14: 17$ & 23.29 & 121.53 & 40.06 & 5.08 & 120 & 50 & 285 & 41 & 82 & 81 & 203 & 5 & $\mathrm{~T}$ \\
\hline 33 & Jun. 17, 1994 & $11: 18$ & 23.9 & 121.5 & 22.01 & 5.01 & 70 & 70 & 250 & 20 & 160 & 25 & 340 & 65 & $\mathrm{~T}$ \\
\hline 34 & Jun. 30, 1994 & $23: 45$ & 23.99 & 121.54 & 12.44 & 4.99 & 110 & 40 & 20 & 90 & 323 & 33 & 77 & 33 & $\mathrm{~T}$ \\
\hline 35 & Jul. 5, 1994 & 09:09 & 23.31 & 121.59 & 18.18 & 4.82 & 70 & 50 & 327 & 75 & 280 & 40 & 24 & 16 & $\mathrm{~T}$ \\
\hline 36 & Jul. 6, 1994 & $21: 21$ & 23.96 & 121.56 & 7.66 & 4.18 & 45 & 89 & 315 & 30 & 288 & 38 & 162 & 38 & $\mathrm{~T}$ \\
\hline 37 & Jan. 10, 1995 & $07: 55$ & 23.68 & 121.41 & 14.06 & 5.12 & 20 & 35 & 212 & 56 & 297 & 11 & 146 & 77 & $\mathrm{~T}$ \\
\hline 38 & Jan. 28, 1995 & $00: 38$ & 23.6 & 121.57 & 32.05 & 4.19 & 135 & 55 & 298 & 36 & 79 & 78 & 218 & 10 & $\mathrm{~T}$ \\
\hline 39 & Feb. 23, 1995 & $06: 27$ & 24.13 & 121.7 & 34.52 & 4.64 & 355 & 30 & 209 & 64 & 287 & 18 & 149 & 67 & $\Upsilon$ \\
\hline 40 & Feb. 26, 1995 & 08:08 & 23.08 & 121.41 & 22.76 & 4.87 & 60 & 55 & 195 & 45 & 129 & 5 & 27 & 65 & $\mathrm{~T}$ \\
\hline 41 & Mar. 9, 1995 & $10: 28$ & 23 & 121.41 & 25.93 & 4.48 & 15 & 50 & 248 & 54 & 312 & 2 & 218 & 61 & $\mathrm{~T}$ \\
\hline 42 & May. 1, 1995 & $14: 50$ & 24 & 121.62 & 12.27 & 4.89 & 275 & 85 & 11 & 40 & 334 & 29 & 220 & 37 & $\mathrm{~T}$ \\
\hline 43 & May. 2, 1995 & $06: 17$ & 24.03 & 121.6 & 8.93 & 4.59 & 105 & 50 & 15 & 89 & 323 & 27 & 68 & 27 & $\mathrm{~T}$ \\
\hline 44 & May. 9, 1995 & 01:03 & 23.01 & 121.37 & 22.61 & 4.9 & 20 & 40 & 225 & 53 & 304 & 7 & 187 & 75 & $\mathrm{~T}$ \\
\hline 45 & May. 9, 1995 & $09: 36$ & 23.55 & 121.57 & 29.26 & 4.61 & 10 & 35 & 245 & 68 & 315 & 18 & 193 & 58 & $\mathrm{~T}$ \\
\hline 46 & May. 27, 1995 & $18: 11$ & 23.04 & 121.35 & 22.68 & 5.26 & 10 & 40 & 227 & 56 & 300 & 8 & 188 & 70 & $\mathrm{~T}$ \\
\hline 47 & May. 27, 1995 & $20: 51$ & 23 & 121.34 & 24.41 & 4.2 & 145 & 50 & 42 & 75 & 99 & 16 & 355 & 40 & $\mathrm{~T}$ \\
\hline 48 & Jun. 6, 1995 & $23: 21$ & 23.04 & 121.35 & 22.91 & 5.06 & 15 & 45 & 245 & 57 & 312 & 7 & 210 & 62 & $\mathrm{~T}$ \\
\hline
\end{tabular}


Table 1. (continued)

\begin{tabular}{|c|c|c|c|c|c|c|c|c|c|c|c|c|c|c|c|}
\hline $\begin{array}{l}\text { Letters on } \\
\text { Fig. } 3\end{array}$ & Date $^{a}$ & $\begin{array}{c}\text { Origin } \\
\text { Time }^{\mathrm{a}} \text {, } \\
\text { UT }\end{array}$ & $\begin{array}{l}\text { Lat., }^{a} \\
{ }^{\circ} \mathrm{N}\end{array}$ & $\begin{array}{l}\text { Lon., } \\
{ }^{\circ} \mathrm{E}\end{array}$ & $\begin{array}{l}\text { Depth }^{a} \\
(\mathrm{Km})\end{array}$ & $\begin{array}{c}\text { Local } \\
\text { Magnitude }^{\mathrm{a}}\end{array}$ & $\begin{array}{l}\text { Plane } \\
\text { Strike } \\
\text { deg }\end{array}$ & $\begin{array}{c}1 \\
\text { Dip } \\
\text { deg }\end{array}$ & $\begin{array}{c}\text { Plane } \\
\begin{array}{c}\text { Strike } \\
\text { deg }\end{array}\end{array}$ & $\begin{array}{c}2 \\
\text { Dip } \\
\text { deg }\end{array}$ & $\frac{\mathrm{P}}{\text { Azimuth }}$ & $\begin{array}{c}\text { Axis } \\
\text { Plunge } \\
\text { deg }\end{array}$ & $\frac{\mathrm{T}}{\mathrm{Azimuth}}$ & $\begin{array}{c}\text { Axis } \\
\text { Plunge } \\
\text { deg }\end{array}$ & Reference $^{b}$ \\
\hline 49 & Aug. 7, 1995 & $16: 17$ & 23.04 & 121.16 & 17.44 & 3.46 & 25 & 55 & 250 & 45 & 136 & 5 & 238 & 65 & $\mathrm{~T}$ \\
\hline 50 & Dec. 2,1995 & $11: 36$ & 23.98 & 121.55 & 6.8 & 3.72 & 195 & 80 & 302 & 31 & 262 & 29 & 136 & 47 & $\mathrm{~T}$ \\
\hline 53 & Dec. 20,1995 & $23: 56$ & 24.05 & 121.71 & 33.74 & 5.06 & 0 & 40 & 193 & 51 & 277 & 6 & 147 & 81 & $\mathrm{~T}$ \\
\hline 54 & Dec. 25,1995 & 19:05 & 22.96 & 121.38 & 15.15 & 4.94 & 165 & 60 & 260 & 81 & 127 & 28 & 29 & 14 & $\mathrm{~T}$ \\
\hline 55 & Jan. 20, 1996 & $04: 24$ & 23.34 & 121.37 & 19.13 & 4.6 & 100 & 60 & 329 & 41 & 321 & 63 & 211 & 10 & $\mathrm{~T}$ \\
\hline 56 & Mar. 5, 1996 & $21: 18$ & 23.03 & 121.38 & 24.07 & 4.81 & 20 & 30 & 223 & 62 & 305 & 16 & 158 & 71 & $\mathrm{~T}$ \\
\hline 57 & Apr. 10, 1996 & $14: 14$ & 23 & 121.43 & 19.19 & 4.65 & 40 & 15 & 230 & 75 & 318 & 30 & 144 & 60 & K1998 \\
\hline 58 & Jun. 9, 1996 & 01:30 & 24.01 & 121.58 & 48.92 & 4.93 & 65 & 75 & 327 & 61 & 289 & 32 & 194 & 9 & $\mathrm{~T}$ \\
\hline 59 & Sep. 5, 1996 & $23: 42$ & 22.04 & 121.32 & 9.76 & 7.07 & 45 & 35 & 225 & 55 & 135 & 80 & 315 & 10 & $\mathrm{~T}$ \\
\hline 60 & Sep. 6, 1996 & 02:04 & 21.94 & 121.37 & 9.03 & 5.5 & 175 & 70 & 276 & 62 & 227 & 5 & 133 & 35 & $\mathrm{~T}$ \\
\hline 61 & Sep. 12, 1996 & $18: 25$ & 23.59 & 121.56 & 29.72 & 4.01 & 20 & 35 & 246 & 64 & 318 & 16 & 196 & 63 & $\mathrm{~T}$ \\
\hline 62 & Nov. 1, 1996 & 09:08 & 23.21 & 121.43 & 21.14 & 4.65 & 175 & 85 & 267 & 70 & 129 & 18 & 222 & 10 & $\mathrm{~T}$ \\
\hline 63 & Dec. 18,1996 & $02: 50$ & 22.9 & 121.27 & 11.84 & 4.86 & 80 & 35 & 350 & 90 & 290 & 35 & 50 & 35 & $\mathrm{~T}$ \\
\hline 64 & Dec. 20,1996 & $10: 50$ & 23.21 & 121.4 & 20.65 & 4.39 & 15 & 50 & 225 & 44 & 119 & 3 & 220 & 74 & $\mathrm{~T}$ \\
\hline 65 & Jan. 8, 1997 & $12: 14$ & 22.83 & 121.3 & 7.29 & 4.06 & 120 & 75 & 227 & 42 & 70 & 45 & 181 & 20 & $\mathrm{~T}$ \\
\hline 66 & Jan. 16, 1997 & 01:07 & 22 & 121.39 & 27.76 & 5.37 & 105 & 70 & 202 & 71 & 333 & 1 & 64 & 28 & $\mathrm{~T}$ \\
\hline 67 & Feb. 13, 1997 & 08:29 & 23.2 & 121.44 & 21.82 & 4.69 & 10 & 65 & 253 & 46 & 128 & 11 & 232 & 52 & $\mathrm{~T}$ \\
\hline 68 & Oct. 22, 1997 & $11: 16$ & 22.58 & 121.39 & 20.18 & 5.3 & 85 & 50 & 349 & 82 & 299 & 34 & 44 & 21 & $\mathrm{~T}$ \\
\hline 69 & Jan. 18, 1998 & $19: 56$ & 22.77 & 121.04 & 2.61 & 5.07 & 195 & 75 & 105 & 89 & 151 & 11 & 59 & 11 & $\mathrm{~T}$ \\
\hline 70 & Jan. 20, 1998 & 23:29 & 22.7 & 121.06 & 5.49 & 5.07 & 100 & 85 & 192 & 70 & 148 & 10 & 54 & 18 & $\mathrm{~T}$ \\
\hline
\end{tabular}

${ }^{a}$ Event dates, epicenters (Lat., latitude; Lon., longitude), local magnitudes are those reported by the Central Weather Bureau.

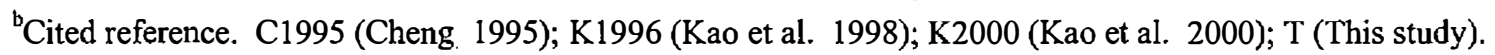


The P- and T-axes for all the mechanisms mentioned above in eastern Taiwan are shown in Fig. 4 and Table 1. Compilation of Fig. 4 has involved specifying which of the nodal planes in each solution was the fault plane and needs some justification. In case of almost pure dipslip faulting (such as events 9,13 , and 34) the direction is insensitive to the choice of fault plane. Some choices were made because the earthquake occurred close to known active or historical surface faulting (events 30,31 , and 37) or were associated with topography that make the choice more likely (events 7, 23, 29, 49, 69, and 70). Apart from three events (events 4,20 , and 28), the pattern for the region shows mainly NW-SE trending (Fig. 3). Similarly, there is broad clustering towards near-horizontal NE-SW extension. However, the APSZ shows T-axis directions that are quite distinct from the horizontal ones found in the LVSZ. A depth section in the E-W direction of the $\mathrm{P}$ - and T-axes of the events located south of $23.2^{\circ} \mathrm{N}$ is shown in Fig. 5.

\section{DISCUSSION}

As shown in the earthquake focal mechanisms (Fig. 3), frequent seismicity (Fig. 1), and GPS observations (Fig. 2), the eastern Taiwan collision zone is characterized by strong compression oriented approximately perpendicular to the major structural trend of the Luzon arc. Oblique plate-convergence would also produce arc-parallel gradients in the horizontal shear stress on plate-boundary faults, that in turn results in arc-parallel stretching or compression of the forearc (McCaffrey 1992). For example, GPS measurements (Fig. 2b) indicate that the velocities of Lutao and Lanhsu are larger than those of other stations to the east of Longitudinal Valley and are in the order of about $20 \mathrm{~mm} / \mathrm{yr}$. In other words, part of the plate convergence is accommodated by deformation between the eastern flank of the Central Range and the Luzon arc, i.e., the Luzon forearc area. In fact, previous studies (e.g., Dahlen et al. 1984; Byrne and Fisher 1990; Shyu et al. 1996; Kao et al. 2000), have noted that the forearc basin and the accretionary prism located to the west of the Luzon arc are of low strength and can deform easily in response to plate convergence. However, the deformation pattern, and its boundaries, for the closing Luzon forearc are relatively unknown.

\subsection{Significance of the Longitudinal Valley and Arc-Parallel Seismic Zones}

The oblique collision between the Luzon arc and continental shelf started near the Hualien area about 4 million years ago, and moved progressively southward to reach Taitung about 1 million years ago (Lee et al. 1991). The spacing between the Luzon arc and Taiwan, measured from Lutao to the Longitudinal Valley, is about $50 \mathrm{~km}$ and decreases northwards (Fig. 1). In a modern arc-trench system, the minimum distance of the spacing between arc and trench is about $100 \mathrm{~km}$. If the Longitudinal Valley represents an ancient trench, the closing between the Luzon arc and Longitudinal Valley implies that most of the forearc block has been shortened or plunged into the mantle (e.g., Cheng et al. 1999; Malavieille et al. 1999).

The stress regime of the LVSZ and APSZ, as inferred from the earthquake strain axes, appears to be dominated by subhorizontal compression (Fig. 4a and Table 1). In general, the Paxes of events in the APSZ and LVSZ show an orientation of $300^{\circ} \pm 30^{\circ}$. This is indistin- 
(a) P-AXIS

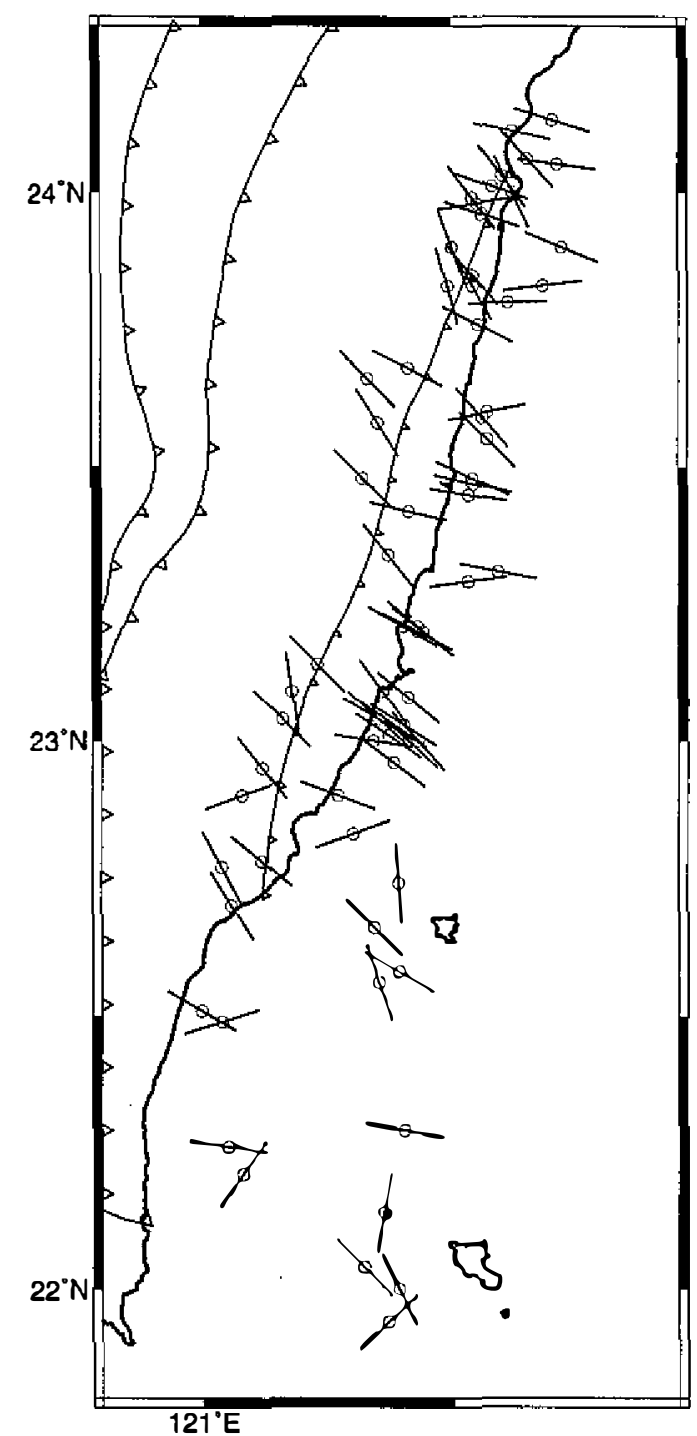

(b) T-AXIS

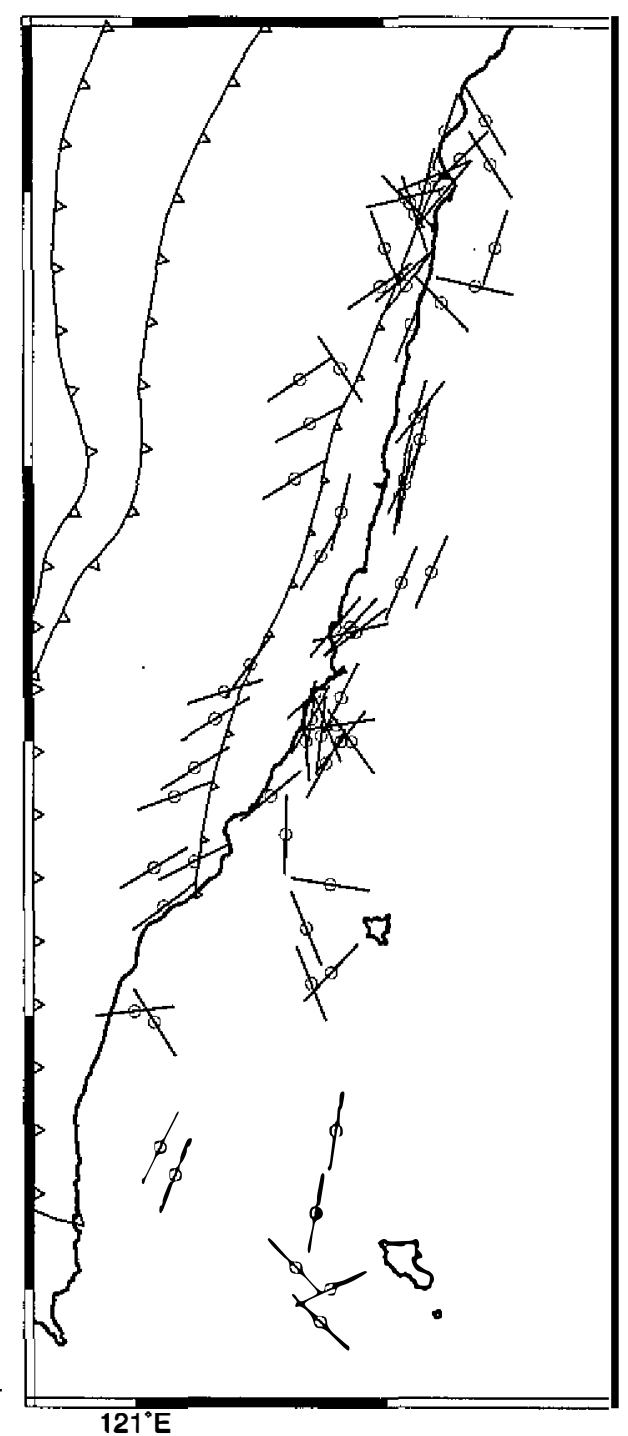

Fig. 4. Map of horizontal projections and locations of the P- (left) and T- (right) axes for earthquakes shown in Fig. 3. Details are the same as for Fig. 3 and Table 1.

guishable from the average $\mathrm{P}$-axis azimuth of $295^{\circ}$ and $297^{\circ}$ for the region north and south of $23^{\circ}$, respectively, determined by Kao et al. (2000). It is also consistent with the azimuth of the axes of maximum relative shortening in eastern Taiwan determined geodetically (Yu et al. 1997). In addition, low-angle thrusting mechanisms near the plate interface, indicative of strikeslip motion between the plates, do not extend deeper (Fig. 5). On the other hand, the orienta- 


\section{(a) P-axes}

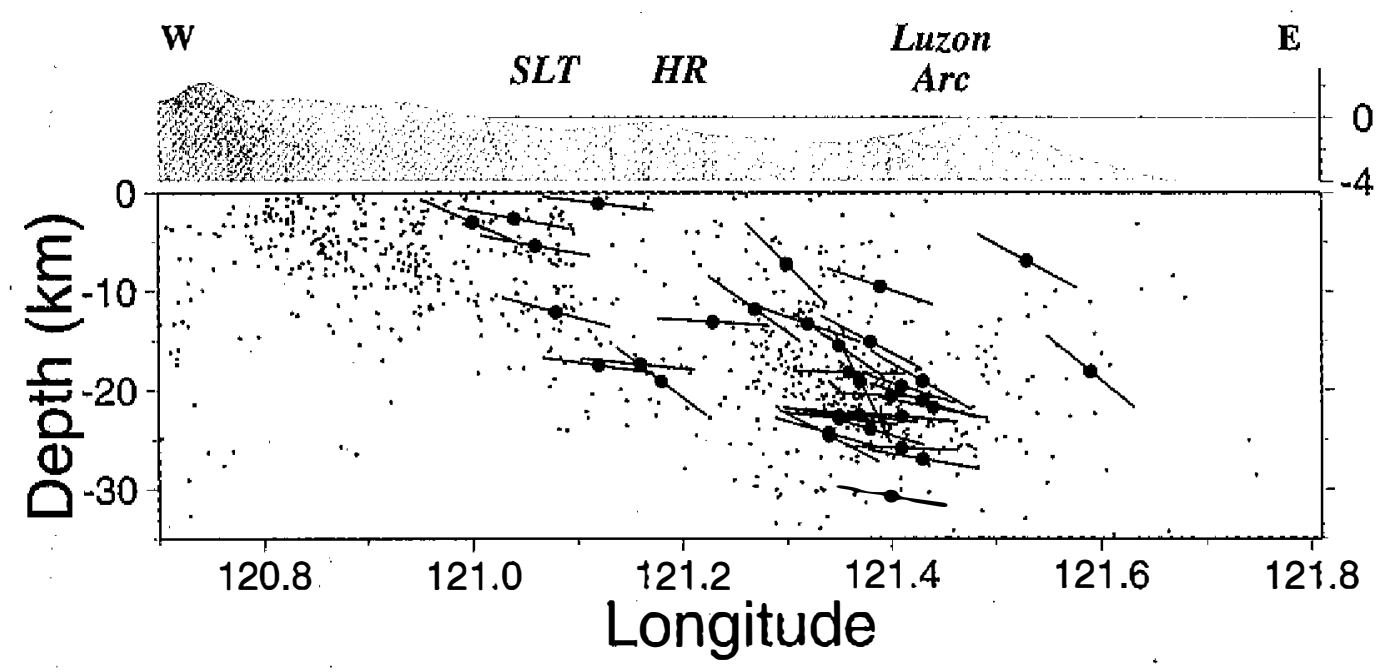

\section{(b) T-axes}

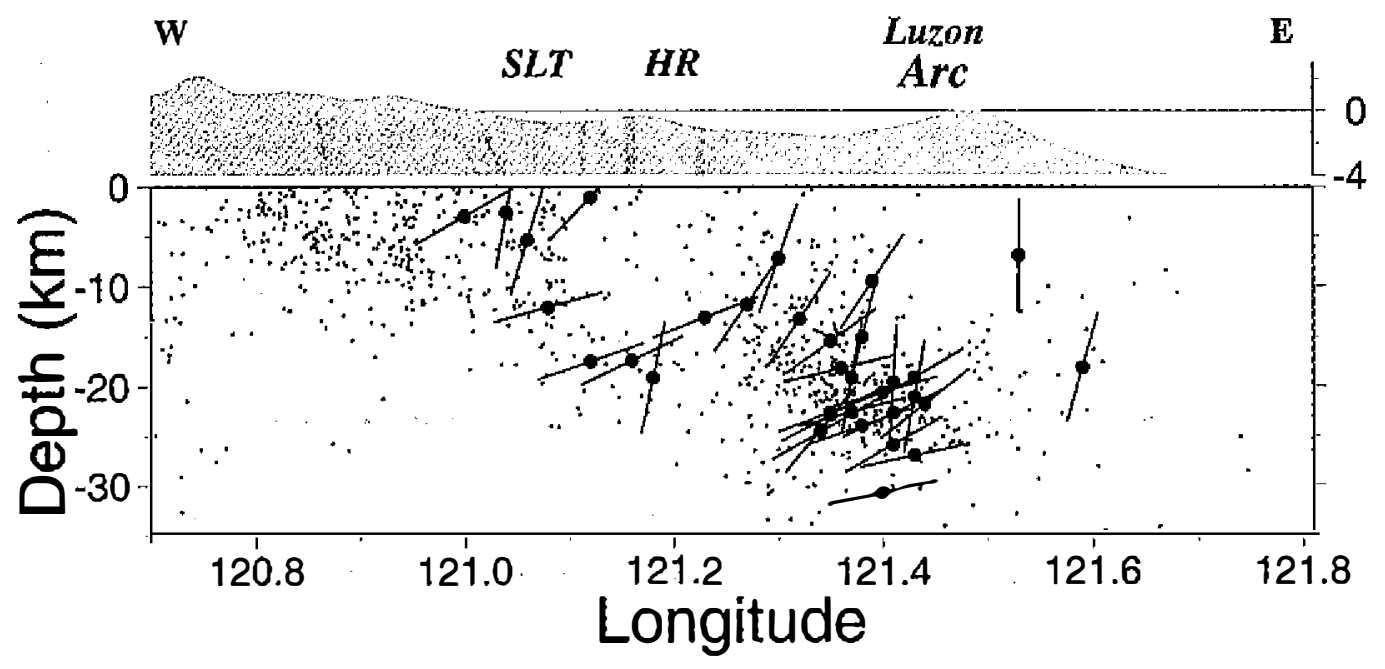

Fig. 5. Depth section of the seismiogenic zones in eastern Taiwan, together with projections of the $\mathrm{P}$ - and $\mathrm{T}$-axes for the events located south of $23.2^{\circ} \mathrm{N}$ determined in this study. HR: Hengchun Ridge; SLT: Southem Longitudinal Trough. Solid dots represent hypocenters of earthquakes relocated with 3-D velocity model. 
tion of the T-axes indicates that there are different patterns for the APSZ and LVSZ in eastern Taiwan. The T-axes clustered in the azimuth, average $234^{\circ} \pm 20^{\circ}$ for the LVSZ events, and $190^{\circ} \pm 30^{\circ}$ for the APSZ events. The average azimuth of the T-axes of events in the APSZ is rotated some $44^{\circ}$ anticlockwise out of the average azimuth of the LVSZ.

By combining evidence from seismicity (Figs. 1 and 3, and Table 1), P- and T-axes (Figs. 4 and 5) and detailed bathymetry, we infer that the development of the APSZ and LVSZ has important tectonic implication. Our study suggests that both might mark obvious east and west boundaries of the Luzon forearc. It has been proposed that for high angles of oblique plate convergence, the thrust wedge will move laterally relative to the underthrust slab and separates from the upper plate by a strike-slip fault, defining a forearc sliver (e.g., Platt 1993). Although the plate-convergence angle between the Eurasian and Philippine Sea plates is larger than $60^{\circ}$ if the Longitudinal Valley plays as a plate interface, we can regard the APSZ as one component accommodating the transfer of oblique slip. This is physically reasonable because the more the Luzon forearc sliver is indenting the Eurasian continental margin, the higher resistance against the forearc sliver expected. This also probably explains why the seismicity of the APSZ is more active than that of the LVSZ (Fig. 1).

\subsection{Luzon Forearc Deformation}

Figure 3 indicates that several moderate strike-slip events (events $17,28,60,66$, and 68) occurred in the APSZ in the area south of $23.2^{\circ}$ (Fig. 3). In this region, the oblique convergence between Philippine Sea and Eurasian plates might have been partitioned into shortening in the Luzon forearc and right-lateral strike-slip in eastem Taiwan. However, the partitioning is not perfect, as the complex pattern of focal mechanisms north of about $23.2^{\circ} \mathrm{N}$ shows. Because the right-lateral strike-slip motion in eastern Taiwan might be accommodated by seismic slip on the major Longitudinal Valley faults, the Luzon forearc must be deforming mostly aseismically, either by creeps on faults or by folding as revealed in seismic reflection data (Fuh et al. 1997; Lundberg et al. 1997). Therefore, it might be expected that the shear strength of the Luzon forearc is relatively small, such that the deformation and large strike-slip fault in the forearc would take place due to the lateral component of the relative plate convergence. Many low-angle thrust events lie within-the dipping seismic zone (Fig. 5) and thus represent the deformation of the forearc area.

As mentioned above, the Luzon forearc is located between the Luzon arc and Central Range in eastern Taiwan. The seismological data presented in this paper confirm that the Luzon forearc is undergoing a marked tectonic evolution and provides further evidence of active compression along its external front, as shown in Fig. 3: We propose that the obliquity of the plate convergence vector resulted in (1) a stress field with NE-SW extension, (2) generation of NW-SE fractures, and (3) sinistral shear along the LVSZ and APSZ. Figure 6 is not intended as a realistic sketch of the tectonic evolution of the region, but merely as an illustration of the sort of processes that might occur. This model is based on focal mechanisms, seismicity, as well as geodetic, geological, and topographic data. Given the Luzon arc trend of $5^{\circ}$, a convergence rate of $7 \mathrm{~cm} / \mathrm{yr}$, and total partitioning of the strike-slip component of the plate slip vector $\left(310^{\circ}\right)$ into the Luzon arc, this tectonic setting likely resulted in sinistral slip 


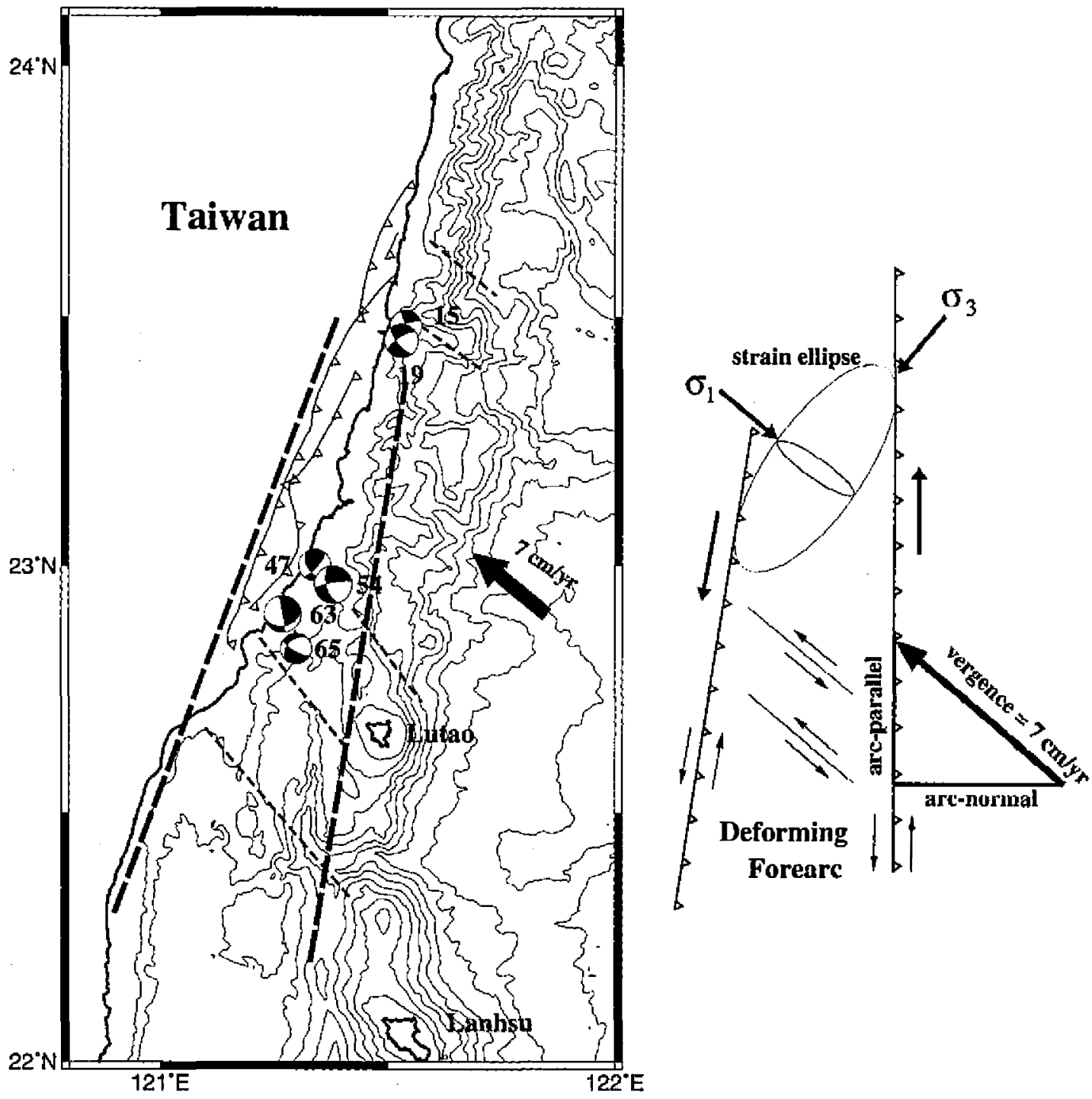

Fig. 6. Schematic diagram showing the Luzon forearc deformation. Left shows several strike-slip solutions inside the Luzon forearc obtained in this study. Heavy dashed lines represent roughly the east and west boundaries of the forearc. Thin dashed lines indicate active strike-slip faults observed in reflection data (e.g., Fuh et al. 1997; Lallemand et al. 1999; Malavieille et al. 1999). Right figure shows transpressional model for the Luzon forearc block. Note the strike-slip faults inside the forearc block also develop or coincide with thrust faults occurring on both sides. 
along the Luzon forearc deformation zone and generation of a stress field with NE-SW extension. During sinistral deformation, $\sigma_{1}$ and $\sigma_{3}$ lay in the horizontal plane, oriented approximately NW-SE and NE-SW respectively, and $\sigma_{2}$ is vertical. In Fig. 6, the Central Range and Luzon arc units represent relatively rigid blocks for the upper crust, which has also been proposed by seismic tomographic study in southeastern Taiwan (Cheng et al. 1998).

We know that the existence of a stress field in the lithosphere is the result of the interaction of tectonic forces whose magnitude and direction vary extremely slowly. Moreover, earthquakes are mostly related to already existing faults, or fault systems in the lithosphere, and these serve as stress concentrators. The forearc unit represents a deforming zone between the two rigid blocks that undergoes simple shearing from the transcurrent component of oblique collision (Fig. 6). The typical effects should occur, such as the formation of en-echelon fold and thrust belts and extensional features that parallel the directions of minimum and maximum compression (e.g., Teyssier et al. 1995). The existence of tensile fracture in a fault system can play an important role because the strike slip displacement can take place not only along the primary faults, but also along the planes of tensile fractures (e.g., Špičák, and Lokajíček, 1986). In addition, strike-slip faults, might also develop or coincide with thrust faults (Sanderson and Marchini 1984). The oblique fold and fault systems of the Coastal Range (left in Fig. 6) and the APSZ and LVSZ in eastern Taiwan could be explained with this model (right in Fig. 6).

\section{CONCLUDING REMARKS}

Knowledge of the state of stress in the convergent plate boundary is an important constraint on our understanding on seismic and aseismic faulting, the force of resisting plate motion, and the rheology of the crust. To better understand the nature of the seismogenic zone in eastern Taiwan and crustal deformation, focal mechanisms of 70 relocated events generally shallower than $30 \mathrm{~km}$ have been determined using P-wave first motion polarity data. The geographical distribution of such events has allowed us to map the seismic strain field of the seismogenic zones in eastern Taiwan. In general, focal mechanisms of events located in the arc-parallel seismic zone (APSZ) and the Longitudinal Valley seismic zone (LVSZ) show mainly thrust and strike-slip solutions in the area south of $23.2^{\circ} \mathrm{N}$.

The P-axes for events in both the APSZ and LVSZ are generally oriented in the direction of plate convergence, suggesting some degree of coupling of the plate interface at this depth. However, the orientation of the T-axes indicates that there are different pattems for the APSZ and LVSZ in eastern Taiwan. We infer that these two seismic zones might mark east and west boundaries of the Luzon forearc.

We have developed a transpressional model to explain important tectonic features of the Luzon forearc. Our tectonic model illustrates the pervasive effects of oblique collision processes, combined with subsequent transpressive forces generated by the motion of the forearc sliver parallel to the continental margin. This model suggests that the Luzon forearc deformation plays an important role in accommodating the oblique convergence in eastern Taiwan.

Acknowledgements We would like to express out appreciation to the Seismological Observation Center, Central Weather Bureau, for providing the earthquake data. We also benefited 
from discussions with Honn Kao, Cheng-Sein Liaw and Chao-Shing Lee. The anonymous reviewers also provided helpful comments. The research was supported by the National Science Council, under grant NSC 89-2116-M-052-001.

\section{REFERENCES}

Angelier, J., H. T. Chu, and J. C. Lee, 1995: Shear concentration in a collision zone: kinematics of the active Chihshang Fault, Longitudinal Valley, eastern Taiwan. In: H. H. Tsien (Ed.), ACT Int. Conf., Ext. Abstr. Geol. Soc. China Spec. Publ., Taipei, pp. 17-24.

Angelier, J., H. T. Chu, J. C., and Lee, 1997: Shear concentration in a collision zone: kinematics of the Chihshang Fault as revealed by outcrop-scale quantification of active faulting, Longitudinal Valley, eastern Taiwan. Tectonophysics, 274, 117-143.

Barrier, E., and J. Angelier, 1986, Active collision in eastern Taiwan: the Coastal Range. Tectonophysics, 125, 39-72.

Bowin, C., R. S. Lu, C. S. Lee, and H. Schouten, 1978: Plate convergence and accretion in the Taiwan-Luzon region. Am. Assoc. Petro. Geol. Bull., 62, 1645-1672.

Byrne, T., and D. Fisher, 1990: Evidence for a weak and overpressured decollement beneath sediment-dominated accretionary prisms. J. Geophys. Res., 95, 9081-9097.

Chemenda, A. I., R. K. Yang, C. H. Hsieh, and A. L. Groholsky, 1997: Evolutionary model for the Taiwan collision based on physical modeling. Tectonophysics, 274, 253-274.

Chen, M. -P., and W. S. Juang, 1986: Seafloor physiography off southeastern Taiwan. Acta Oceanogr. Taiwanica, 16, 1-7.

Cheng, S. N., 1995: The study of stress distribution in and around Taiwan [Ph. D. dissert]. Chung-Li, Taiwan, National Central University, 215 p. (in Chinese)

Cheng, W. B., C. Wang, C. T. Shyu, and T. C. Shin, 1998: A three-dimensional Vp model of the southeastern Taiwan area and its tectonic implications. TAO, 9, 425-452.

Cheng, W. B., C. Wang, C. T. Shyu, and T. C. Shin, 1999: Crustal structure of the convergent plate-boundary zone, eastern Taiwan, assessed by seismic tomography. Geol. Soc. Am. Spec. (in press)

Dahlen, F. A., J. Suppe, and D. M. Davis, 1984: Mechanics of fold-and thrust belts and accretionary wedges: Cohesive Coulomb theory. J. Geophys. Res., 89, 10087-10101.

Fuh, S. C., C. S. Liu, N. Lundberg, and D. L. Reed, 1997: Strike-slip faults offshore southern Taiwan: implications for the oblique arc-continent collision processes. Tectonophysics, 274, 25-39.

Ho, C., 1982: Tectonic Evolution of Taiwan. Explanatory Text of the Tectonic Map of Taiwan. Ministry of Economic Affairs, Taipei, $126 \mathrm{pp}$.

Ho, C., 1986: A synthesis of the geologic evolution of Taiwan. Tectonophysics, 125, 1-16.

Hsu, T. L., 1962: Recent faulting in the Longitudinal Valley of eastern Taiwan. Mem. Geol. Soc. China, 1, 95-102.

Kao, H., P. R. Jian, K. F. Ma, B. S. Huang, and C. S. Liu, 1998: Moment-tensor inversion of offshore earthquakes east of Taiwan and their implications to regional collision. Geophys. Res. Lett., 25, 3619-3622. 
Kao, H., G. C., Huang, and C. S. Liu, 2000: Transition from oblique subduction to collision in the northern Luzon arc-Taiwan region, Constraints from bathymetry and seismic observations. J. Geophys. Res., 105, 3059-3079.

Lallemand, S., C. S. Liu, J. Malavielle, P. Schnurle, S. Dominguez, and the ACT scientific crew, 1999: Trench-parallel stretching and folding of forearc basins and lateral migration of the accretionary wedge in the southern Ryukyus: a case of strain partition caused by oblique convergence. Tectonics, 18, 231-247.

Lee, T. Q., C. Kissel, E. Barrier, C. Laj, and W. R. Chi, 1991: Paleomagnetic evidence for a diachronous clockwise rotation of the Coastal Range, eastern Taiwan. Earth Planet. Sci. Lett., 104, 245-257.

Liu, S. -Y., C. S. Liu, D. Reed, and N. Lundberg, 1992: Analysis of the tectonic structures in the region off southeastern Taiwan based on gravity-magnetic data. Proc. Taiwan Symposium on Geophys., 4th: Taipei, Taiwan, p. 575-585.

Lundberg, N., D. L. Reed, C. S. Liu. and J. Lieske Jr., 1997: Forearc-basin closure and arc accreation in submarine suture zone south of Taiwan. Tectonophysics, 274, 5-23.

Malavieille, J., S. E. Lallemand, S. Dominguez, A. Deschamps, C. Y. Lu, C. S. Liu, P. Schnurle, and the ACT Scientific Crew, 1999: Arc-continent collision in Taiwan: new marine observations and tectonic evolution. Geol. Soc. Am. Spec. (in press)

McCaffrey, R., 1992: Oblique plate convergence, slip vectors, and forearc deformation. $J$. Geophys. Res., 97, 8905-8915.

McCaffrey, R., 1994: Global variability in subduction thrust zone forearc systems. Pure App. Geophys., 142, 173-224.

Page, B. M., and J. Suppe, 1981: The Pliocene Lichi Melange of Taiwan: its plate tectonic and olistostromal origin. Am. J. Science, 281, 193-277.

Platt, J. P., 1993: Mechanics of oblique convergence. J. Geophys. Res., 98, 16239-16256.

Reasenberg, P., and D. Oppenheimer, 1985, FPFIT, FPPLOT and FPPAGE: FORTRAN computer programs for calculating and displaying earthquake fault-plane solutions: USGS Open file Rept, 87-739.

Richard, M., H. Bellon, R. C. Maury, E. Barrier, and W. S. Juang, 1986: Miocene to recent calc-alkalic volcanism in eastern Taiwan: $\mathrm{K}-\mathrm{Ar}$ ages and petrography. Tectonophysics, 125, 87-102.

Sanderson, D., and R. D. Marchini, 1984: Transpression. J. Struct. Geol., 6, 449-458.

Seno, T., 1977: The instantaneous rotation vector of the Philippine Sea plate relative to the Eurasian plate. Tectonophysics, 42, 209-226.

Shyu, C. T., M. C. Chih, S. K. Hsu, C. Wang, and B. Karp, 1996: Northern Luzon arc: location and tectonic features from magnetic data off eastern Taiwan. TAO, 7, 535-548.

Špičák, A., and T. Lokajíček, 1986: Fault interaction and seismicity: laboratory investigation and its seismotectonic interpretation. Pure Appl. Geophys., 124, 857-874.

Teyssier, C. B. Tikoff, and M. Markley, 1995: Oblique plate motion and continental tectonics. Geology, 23, 447-450.

Thurber, C. H., 1993: Local earthquake tomography: Velocities and $V_{\mathrm{p}} \mathrm{N}_{\mathrm{s}}$ - Theory, in Iyer, H. M., and Hirahara, K., ed., Seismic Tomography: Theory and Practice: Chapman and Hall, New York, 563-583. 
Thurber, C., and D. Eberhart-Phillips, 2000: Local earthquake tomography with flexible gridding. Computer \& Geosciences, 25, 809-818.

Tsai, Y. B., 1986: Seismotectonics of Taiwan. Tectonophysics, 125, 17-37

Yu, S. B., H. Y. Chen, and L. C. Kuo, 1997: Velocity field of GPS stations in the Taiwan area. Tectonophysics, 274, 41-59. 